\title{
Antimicrobial Resistance in Bacteria Isolated from Foods in Cuba
}

\author{
Yamila Puig-Peña MD MS, Virginia Leyva-Castillo MS, René Tejedor-Arias PhD, María Teresa Illnait-Zaragozí MD PhD, \\ Neibys Aportela-López, Ailen Camejo-Jardines, Jesy Ramírez-Areces
}

\begin{abstract}
INTRODUCTION Antimicrobial drug resistance constitutes a health risk of increasing concern worldwide. One of the most common avenues for the acquisition of clinically-relevant antimicrobial resistance can be traced back to the food supply, where resistance is acquired through the ingestion of antimicrobial resistant microorganisms present in food. Antimicrobial resistance constitutes a health risk, leading to production losses and negative consequences for livelihood and food safety.
\end{abstract}

OBJECTIVE Determine whether resistant bacteria are present in foods in Cuba.

METHODS A descriptive observational study was conducted in the Microbiology Laboratory of Cuba's National Institute of Hygiene, Epidemiology and Microbiology from September 2004 through December 2018. Researchers analyzed 1178 bacterial isolates from food samples. The isolates were identified as Escherichia coli, Salmonella, Vibrio cholerae and coagulase-positive Staphylococcus. The antimi-

\section{INTRODUCTION}

Antimicrobial resistance (AMR) is a health risk worldwide, leading to production losses and negative effects on livelihood, food safety and the economy,[1] including in Cuba. Statistics from the national program for prevention and control of healthcare-associated infections show an increase in resistance to the most commonly used hospital antibiotics in the last few years, as well as longer hospitalizations and higher spending on these infections.[2] The public health sector is acting to promote the rational prescription and use of antimicrobials, and is conducting various susceptibility studies on clinically-obtained isolates.[3] However, there are few reports on antimicrobial-resistant foodborne bacteria.

Quantitatively, foodborne AMR is the most common route for the spread of antibiotic-resistant bacteria. The presence of these microorganisms in the food chain, the environment and water can lead to their appearance in the human intestinal microbiome, turning it into a major reservoir for resistant genes in the body. It also increases the risk of their dissemination among commensal bacteria and pathogens that cause intra- and extraintestinal infections.[4]

Among the most clinically important foodborne pathogenic bacteria in AMR are strains of Salmonella and E. coli, which carry extended-spectrum beta lactamases, fluoroquinoloneresistant Campylobacter and Salmonella, and methicillin-resistant Staphylococcus aureus.[5] However, commensal bacteria also found in foods play a key role in AMR evolution and spread.

IMPORTANCE This paper highlights the importance of antimicrobial resistance surveillance in foods commonly consumed in Cuba. crobial susceptibility study was performed using the Bauer-Kirby disk diffusion method, following procedures outlined by the Clinical and Laboratory Standards Institute. The data were analyzed using WHONET version 5.6.

RESULTS Of the total isolates, $62.1 \%$ were resistant to at least one antibiotic. Within each group, $>50 \%$ of isolates showed some type of resistance. E. coli and V. cholerae exceeded $50 \%$ resistance to tetracycline and ampicillin, respectively. Staphylococcus showed the highest resistance to penicillin, and Salmonella to tetracycline, nalidixic acid and ampicillin. The highest percentages of non-susceptible microorganisms were identified in meats and meat products.

CONCLUSIONS These results serve as an alert to the dangers of acquiring antibiotic-resistant bacteria from food and demonstrate the need to establish a surveillance system and institute measures bacterial control in food products.

KEYWORDS Microbial drug resistance, bacteria, food, foodborne disease, Cuba

They predominate in the environment and show greater genetic diversity and host variety in nature, which makes them a potential indicator for AMR. Thus, studying these agents can provide early warning of emerging AMR.[6]

WHO suggests regular, periodic surveillance to address the problem of AMR, with permanent monitoring of changes in its prevalence in humans, animals, foods and the environment.[7] Clearly, it is important to discover foodborne AMR as quickly as possible. This includes studying risks by identifying dangers: antimicrobial-resistant microorganisms, the antimicrobials to which they are resistant, and the food products in which this resistance is found. Cuba has no program dedicated to ongoing surveillance of this problem. For these reasons, this study was performed with the aim of assessing antimicrobial resistance in clinically relevant bacteria isolated from foods in Cuba.

\section{METHODS}

A descriptive observational study was conducted from September 2004 through December 2018 on 1178 isolates identified in foods (381 isolates of E. coli, 402 of Salmonella, 113 of V. cholerae and 282 of coagulase-positive Staphylococcus). The isolates were performed at the Provincial Hygiene, Epidemiology and Microbiology Centers in 13 Cuban provinces and in the Microbiology Laboratory of the National Hygiene, Epidemiology and Microbiology Institute (INHEM) in Havana, following current standards in Cuba.[8-11]

The microorganisms were identified in a variety of 146 foods subject to microbiological surveillance in the study of foodborne disease outbreaks and health inspections of foods before sale. These were categorized in 14 groups, according to Cuban microbiological criteria standard NC 585, 2017.[12] The food types were: 
- Ready-to-eat foods

- Beverages (juices and soft drinks)

- Broths, soups and creams

- Meats and meat products - processed fresh meats sold in pieces and fresh ground meats (poultry, pork, beef); semiprocessed meat products: protein mix, hamburger, sausages, chorizos; processed meat products: mortadella, bologna, smoked products

- Cocao derivatives

- Spices and condiments

- Nutritional supplements of vegetable origin

- Fruits and vegetables

- Eggs and derivatives-prepared eggs: omelets, scrambled eggs and other products; pastry products and egg-based creams

- Milk and dairy products-pasteurized liquid milk, ice cream, cheeses, yogurt

- Fish, seafood and fish products

- Grain-based products

Antimicrobial susceptibility was determined using the Bauer-Kirby disk diffusion method, strictly adhering to procedures established for this purpose by the Clinical and Laboratory Standards Institute (CLSI).[13] The antimicrobial disks (CPM-SCIENTIFICA, Italy) contained the following loads:

\begin{tabular}{|l|r|}
\hline Antimicrobial disk & Antibiotic load $(\boldsymbol{\mu g})$ \\
\hline Nalidixic acid & 30 \\
\hline Amikacin & 30 \\
\hline Ampicillin & 10 \\
\hline Azithromycin & 15 \\
\hline Carbenicillin & 100 \\
\hline Cefotaxime & 30 \\
\hline Ceftazidime & 30 \\
\hline Ceftriaxone & 30 \\
\hline Ciprofloxacin & 5 \\
\hline Chloramphenicol & 30 \\
\hline Doxycycline & 30 \\
\hline Erythromycin & 15 \\
\hline Streptomycin & 10 \\
Gentamicin & 10 \\
\hline Kanamycin & 30 \\
\hline Oxacillin & 5 \\
\hline Penicillin & 10 IU \\
\hline Sulfamethoxazole/trimethoprim & $1.25 / 23.75$ \\
\hline Tetracycline & 30
\end{tabular}

IU: International Units

As part of quality control, Staphylococcus aureus ATCC 25923, E. coli ATCC 25922 and Pseudomonas aeruginosa ATCC 27853 reference strains were used.

Antimicrobials were selected according to bacterial species. For Salmonella and E. coli: nalidixic acid, amikacin, ampicillin, carbenicillin, cefotaxime, ceftriaxone, ceftazidime, ciprofloxacin, chloramphenicol, streptomycin, gentamicin, kanamycin, sulfamethoxazole/trimethoprim and tetracycline were chosen. For Staphylococcus: amikacin, cefotaxime, ceftriaxone, chloramphenicol, ciprofloxacin, erythromycin, gentamicin, kanamycin, penicil- lin, oxacillin, sulfamethoxazole/trimethoprim and tetracycline were selected. For V. cholerae: ampicillin, ciprofloxacin, sulfamethoxazole/trimethoprim, tetracycline, doxycycline and azithromycin were chosen.

Extended-spectrum beta lactamase (ES $\beta L)$ detection was performed on $97 \mathrm{E}$. coli isolates from fresh meats. Isolates with inhibition halos equal to or less than the following diameters were classified as presumptive carriers: cefotaxime $\leq 27 \mathrm{~mm}$, ceftazidime $\leq 22 \mathrm{~mm}$, and ceftriaxone $\leq 25 \mathrm{~mm}$. The disk combination method (CLSI, 2015) and ETEST strips (BioMérieux, France) containing the following combinations were used for confirmation: ceftazidime $(0.5-32 \mu \mathrm{g} / \mathrm{mL})$ and ceftazidime/clavulanic acid $(0.064-4 \mu \mathrm{g} / \mathrm{mL}$ ) (Liofichem, Italy). Results were interpreted following the manufacturer's criteria. $E$. coli ATCC 25922 strains were tested as a negative control, with ES $\beta$ L Klebsiella pneumoniae ATCC 700603 strains tested as a positive control.

Results were analyzed using a database created in WHONET version 5.6, a WHO digital platform for surveillance of antimicrobial resistance and infection control.[14] The antibiogram interpretation criteria cutoff points were updated according to CLSI standards. Susceptibility was analyzed by isolate source, for which contingency tables were established, and the chi-square test was applied with a significance level of $0.05 \%$. The data were processed using the EPIDAT program (EpiData Association, Denmark) for epidemiological analysis of tabular data, version 3.0 of 2004.[15]

Results of the in vitro susceptibility tests were expressed as absolute frequencies and percentages. Isolates with full growth around the antibiotic disk or those in which growth inhibition did not reach the diameter established for the CLSI susceptibility criterion (reduced susceptibility) were considered resistant. Otherwise, they were considered sensitive to the antibiotic.

Ethical considerations No clinical assays were performed on persons or animals in this study, and the study was authorized by INHEM's scientific council. This document contains no company, institution or brand names of foods from which the isolates were obtained.

\section{RESULTS}

AMR was analyzed according to the microorganisms retrieved from different food types (Table 1). Of all isolates, $62.1 \%$ (731/1178) were antibiotic-resistant; of all bacteria studied, AMR was observed in $32.3 \%(236 / 731)$ of Salmonella isolates, $30.1 \%$ (220/731) of E. coli, 29.9\% (212/731) of Staphylococcus and 8.6\% (63/731) of $V$. cholerae. Resistant microorganisms were most often identified in meats and meat products, with Salmonella and E. coli isolates predominating.

Resistance was detected less frequently in bacteria isolated from milk and dairy products, with Staphylococcus and E. coli the most common. In egg-based products, Salmonella and Staphylococcus isolates predominated. A low frequency of isolates was found in all other foods.

V. cholerae was isolated in fruits and vegetables, and in fish, seafood and fishery products, which had the highest percentage of resistant isolates at $69.3 \%$. 
Table 1: Antimicrobial resistance of microorganisms according to food type from which they were recovered. INHEM 2004-2018

\begin{tabular}{|c|c|c|c|c|c|c|c|c|c|c|c|c|c|c|c|}
\hline \multirow{2}{*}{ Food Type } & \multicolumn{3}{|c|}{ Escherichia coli } & \multicolumn{3}{|c|}{ Salmonella } & \multicolumn{3}{|c|}{ Staphylococcus } & \multicolumn{3}{|c|}{ Vibrio cholerae } & \multicolumn{3}{|c|}{ Total } \\
\hline & No. & AMR & $\%^{a}$ & No. & AMR & $\%^{a}$ & No. & AMR & $\%^{a}$ & No. & AMR & $\%^{a}$ & No. & AMR & $\%^{\mathrm{b}}$ \\
\hline Meats and meat products & 215 & 141 & 36.7 & 284 & 173 & 45.1 & 132 & 70 & 18.2 & 0 & 0 & 0.0 & 631 & 384 & 52.5 \\
\hline Milk and dairy products & 85 & 35 & 36.5 & 4 & 4 & 4.2 & 62 & 57 & 59.4 & 0 & 0 & 0.0 & 151 & 96 & 13.1 \\
\hline Eggs and derivatives & 27 & 14 & 17.7 & 67 & 37 & 46.8 & 28 & 28 & 35.4 & 0 & 0 & 0.0 & 122 & 79 & 10.8 \\
\hline Fish, seafood and fish products & 8 & 5 & 6.7 & 16 & 2 & 2.7 & 28 & 16 & 21.3 & 98 & 52 & 69.3 & 150 & 75 & 10.3 \\
\hline Ready-to-eat foods & 22 & 20 & 30.3 & 29 & 19 & 28.8 & 27 & 18 & 27.3 & 0 & 0 & 0.0 & 69 & 66 & 9.0 \\
\hline Fruits and vegetables & 5 & 0 & 0.0 & 0 & 0 & 0.0 & 4 & 4 & 26.7 & 15 & 11 & 73.3 & 24 & 15 & 2.1 \\
\hline Nutritional supplements & 0 & 0 & 0.0 & 1 & 0 & 0.0 & 8 & 8 & 100.0 & 0 & 0 & 0.0 & 9 & 8 & 1.1 \\
\hline $\begin{array}{l}\text { Beverages (juices and soft } \\
\text { drinks) }\end{array}$ & 13 & 4 & 100.0 & 0 & 0 & 0.0 & 0 & 0 & 0.0 & 0 & 0 & 0.0 & 13 & 4 & 0.5 \\
\hline Cocao derivatives & 1 & 1 & 33.3 & 0 & 0 & 0.0 & 2 & 2 & 66.7 & 0 & 0 & 0.0 & 3 & 3 & 0.4 \\
\hline Spices and condiments & 0 & 0 & 0.0 & 1 & 1 & 100.0 & 0 & 0 & 0.0 & 0 & 0 & 0.0 & 1 & 1 & 0.1 \\
\hline Grain-based products & 2 & 0 & 0.0 & 0 & 0 & 0.0 & 0 & 0 & 0.0 & 0 & 0 & 0.0 & 2 & 0 & 0.0 \\
\hline $\begin{array}{l}\text { Broths, soups and cream- } \\
\text { based soups }\end{array}$ & 3 & 0 & 0.0 & 0 & 0 & 0.0 & 0 & 0 & 0.0 & 0 & 0 & 0.0 & 3 & 0 & 0.0 \\
\hline Total \% & 381 & 220 & 30.1 & 402 & 236 & 32.3 & 282 & 212 & 29.0 & 113 & 63 & 8.6 & 1178 & 731 & 100.0 \\
\hline
\end{tabular}

a Percentage refers to total number of isolates in category ${ }^{b}$ Percentage refers to total number of foods analyzed per microorganism AMR: Antimicrobial resistance INHEM: National Institute of Hygiene, Epidemiology and Microbiology

Table 2 shows the relation between AMR in Salmonella, E. coli and Staphylococcus and their isolate sources. Salmonella was not associated with any specific food type. The highest percentage of resistant isolates was found in meats and meat products. E. coli had a higher proportion of resistant isolates compared to subgroup size in meats and meat products. Additionally, Staphylococcus had a higher proportion of resistant isolates found in meat and dairy products.

Table 2: Relation between antibiotic resistance of Escherichia coli, Salmonella and Staphylococcus and food type from which isolates were recovered $(n=1065)$. INHEM 2004-2018

\begin{tabular}{|c|c|c|c|c|}
\hline \multirow{3}{*}{ Susceptibility } & \multicolumn{3}{|c|}{ By Isolate Source } & \multirow{2}{*}{$\begin{array}{c}\mathbf{p} \\
\text { Value }\end{array}$} \\
\hline & \multicolumn{3}{|c|}{ Escherichia coli $(\mathbf{n}=381)$} & \\
\hline & $\begin{array}{l}\text { Meats and meat } \\
\text { products }\end{array}$ & $\begin{array}{l}\text { Milk and dairy } \\
\text { products }\end{array}$ & Other & \\
\hline Sensitive $\%^{a}$ & $74(34.4)$ & $50(58.8)$ & $37(45.7)$ & 0.0000 \\
\hline Resistant $\%^{a}$ & $141(65.6)$ & $35(41.2)$ & $44(54.3)$ & \\
\hline Total \% ${ }^{\mathrm{b}}$ & $215(56.4)$ & $85(22.3)$ & $81(21.3)$ & \\
\hline \multicolumn{5}{|l|}{$X^{2} 22.7709$} \\
\hline \multirow[b]{2}{*}{ Susceptibility } & \multicolumn{3}{|c|}{ Salmonella $(n=402)$} & \multirow{5}{*}{0.3397} \\
\hline & $\begin{array}{l}\text { Meats and meat } \\
\text { products }\end{array}$ & $\begin{array}{l}\text { Eggs and } \\
\text { derivatives }\end{array}$ & Other & \\
\hline Sensitive $\%^{a}$ & $111(39.1)$ & $30(44.8)$ & $25(49.0)$ & \\
\hline Resistant $\%^{a}$ & $173(60.9)$ & $37(55.2)$ & $26(51.0)$ & \\
\hline Total \% ${ }^{\mathrm{b}}$ & $284(70.6)$ & $67(16.7)$ & $51(12.7)$ & \\
\hline \multicolumn{5}{|l|}{$X^{2} 2.1666$} \\
\hline \multirow[b]{2}{*}{ Susceptibility } & \multicolumn{3}{|c|}{ Staphylococcus ( $\mathrm{n}=\mathbf{2 8 2}$ ) } & \multirow{6}{*}{0.0003} \\
\hline & $\begin{array}{l}\text { Meats and meat } \\
\text { products }\end{array}$ & $\begin{array}{l}\text { Milk and dairy } \\
\text { products }\end{array}$ & Other & \\
\hline Sensitive $\%^{a}$ & $52(42.6)$ & $5(8.1)$ & $13(13.3)$ & \\
\hline Resistant \%a & $70(57.4)$ & $57(91.9)$ & $85(86.7)$ & \\
\hline Total \% ${ }^{\mathrm{b}}$ & $122(43.3)$ & $62(22.0)$ & $98(34.8)$ & \\
\hline$X^{2} 16.7991$ & & & & \\
\hline
\end{tabular}

a Percentage refers to total number of isolates in category

${ }^{b}$ Percentage refers to total number of foods analyzed per microorganism INHEM: National Institute of Hygiene, Epidemiology and Microbiology
Resistance by antibiotic type was low overall, except for tetracycline in E. coli and ampicillin in V. cholerae, for which resistance was over $50 \%$ (Table 3). Of the 19 antibiotic agents analyzed (14 for Salmonella and E. coli, 12 for Staphylococcus and 6 for $V$. cholerae) Salmonella expressed in vitro resistance to 12 , and $E$. coli, to 14 . Tetracycline, nalidixic acid and ampicillin showed the highest resistance levels. More than $75 \%$ of Staphylococcus isolates were resistant, mainly against penicillin, erythromicin and tetracycline, in decreasing order. $\mathrm{V}$. cholerae was resistant to three antibiotics, namely tetracycline,

Table 3: Percentage of resistance by antibiotic and microorganism. INHEM 2004-2018

\begin{tabular}{|c|c|c|c|c|c|c|c|c|}
\hline \multirow[t]{2}{*}{ Antibiotic } & \multicolumn{2}{|c|}{$\begin{array}{l}\text { Salmonella } \\
\quad n=236\end{array}$} & \multicolumn{2}{|c|}{$\begin{array}{l}E . \text { coll } \\
n=220\end{array}$} & \multicolumn{2}{|c|}{$\begin{array}{c}\text { Staphylo- } \\
\text { coccus } \\
\mathrm{n}=212\end{array}$} & \multicolumn{2}{|c|}{$\begin{array}{c}\text { V. chol- } \\
\text { erae } \\
n=63\end{array}$} \\
\hline & No. & $\%$ & No. & $\%$ & No. & $\%$ & No. & $\%$ \\
\hline Tetracycline & 140 & 59.3 & 91 & 41.4 & 44 & 20.8 & 3 & 4.8 \\
\hline Nalidixic acid & 70 & 29.7 & 102 & 46.4 & - & - & - & - \\
\hline Ampicillin & 55 & 23.3 & 117 & 53.2 & - & - & 54 & 85.7 \\
\hline Carbenicillin & 31 & 13.1 & 27 & 12.3 & - & - & - & - \\
\hline Ceftriaxone & 14 & 5.9 & 23 & 10.5 & 59 & 27.8 & - & - \\
\hline Ceftazidime & 16 & 6.8 & 13 & 5.9 & - & - & - & - \\
\hline Streptomycin & 8 & 3.4 & 12 & 5.5 & - & - & - & - \\
\hline Cefotaxime & 7 & 3.0 & 13 & 5.9 & 0 & 0 & - & - \\
\hline $\begin{array}{l}\text { Sulfamethoxazole/ } \\
\text { trimethoprim }\end{array}$ & 4 & 1.7 & 40 & 18.2 & 0 & 0 & 6 & 9.5 \\
\hline Chloramphenicol & 2 & 0.8 & 38 & 17.3 & 0 & 0 & - & - \\
\hline Kanamycin & 2 & 0.8 & 15 & 6.8 & 6 & 2.8 & - & - \\
\hline Ciprofloxacin & 2 & 0.8 & 19 & 8.6 & 8 & 3.8 & 0 & 0 \\
\hline Amikacin & 0 & 0 & 11 & 5.0 & 2 & 0.9 & - & - \\
\hline Gentamicin & 0 & 0 & 12 & 5.5 & 1 & 0.5 & - & - \\
\hline Penicillin & - & - & - & - & 88 & 41.5 & - & - \\
\hline Oxacillin & - & - & - & - & 43 & 20.3 & - & - \\
\hline Erythromycin & - & - & - & - & 52 & 24.5 & - & - \\
\hline Azithromycin & - & - & - & - & - & - & 0 & 0 \\
\hline Doxycycline & - & - & - & - & - & - & 0 & 0 \\
\hline
\end{tabular}

INHEM: National Institute of Hygiene, Epidemiology and Microbiology 
Table 4: Isolates studied, by microorganism and province where identified. INHEM 2004-2018

\begin{tabular}{|c|c|c|c|c|c|c|c|c|c|c|}
\hline \multirow{2}{*}{ Province } & \multicolumn{2}{|c|}{ E. coli } & \multicolumn{2}{|c|}{ Salmonella } & \multicolumn{2}{|c|}{ Staphylococcus } & \multicolumn{2}{|c|}{ V. cholerae } & \multicolumn{2}{|c|}{ Total } \\
\hline & No. & $\%^{a}$ & No. & $\%^{a}$ & No. & $\%^{a}$ & No. & $\%^{a}$ & No. & $\%^{b}$ \\
\hline Havana (INHEM) & 263 & 42.4 & 98 & 15.8 & 250 & 40.3 & 10 & 1.6 & 621 & 52.7 \\
\hline Pinar del Río & 64 & 82.1 & 10 & 12.8 & 4 & 5.1 & 0 & 0.0 & 78 & 6.6 \\
\hline Santiago de Cuba & 39 & 30.0 & 67 & 51.5 & 9 & 6.9 & 15 & 11.5 & 130 & 11.0 \\
\hline Las Tunas & 10 & 15.4 & 49 & 75.4 & 6 & 9.2 & 0 & 0.0 & 65 & 5.5 \\
\hline Sancti Spíritus & 2 & 16.7 & 10 & 83.3 & 0 & 0.0 & 0 & 0.0 & 12 & 1.0 \\
\hline Villa Clara & 2 & 3.0 & 65 & 97.0 & 0 & 0.0 & 0 & 0.0 & 67 & 5.7 \\
\hline Granma & 1 & 1.1 & 6 & 6.9 & 0 & 0.0 & 80 & 92.0 & 87 & 7.4 \\
\hline Ciego de Ávila & 0 & 0.0 & 14 & 51.9 & 7 & 25.9 & 6 & 22.2 & 27 & 2.3 \\
\hline Camagüey & 0 & 0.0 & 27 & 96.4 & 0 & 0.0 & 1 & 3.6 & 28 & 2.4 \\
\hline Cienfuegos & 0 & 0.0 & 4 & 66.7 & 2 & 33.3 & 0 & 0.0 & 6 & 0.5 \\
\hline Guantánamo & 0 & 0.0 & 12 & 92.3 & 0 & 0.0 & 1 & 7.7 & 13 & 1.1 \\
\hline Holguín & 0 & 0.0 & 21 & 100.0 & 0 & 0.0 & 0 & 0.0 & 21 & 1.8 \\
\hline Isla de la Juventud* & 0 & 0.0 & 1 & 100.0 & 0 & 0.0 & 0 & 0.0 & 1 & 0.1 \\
\hline Matanzas & 0 & 0.0 & 18 & 81.8 & 4 & 18.2 & 0 & 0.0 & 22 & 1.9 \\
\hline Total & 381 & 32.3 & 402 & 34.1 & 282 & 23.9 & 113 & 9.6 & 1178 & 100.0 \\
\hline
\end{tabular}

a Percentage refers to total number of isolates for province, ${ }^{\mathrm{b}}$ Percentage refers to total number of isolates INHEM: National Institute of Hygiene, Epidemiology and Microbiology ${ }^{*}$ Special Municipality
Since most poultry meats in Cuba are imported,[26] this could be considered a route for spreading resistance, in addition to antibiotics found in imported meat that are not used in domestic animal production, such as cefotaxime, ceftriaxone and ceftazidime.

Resistant E. coli isolates were most often found in pork, mortadella and smoked pork loin. Three isolates carrying ES $\beta$ L were found in imported poultry meat and beef, and in domestically produced pork, at a lower percentage than has been reported in other countries.[27,28]

Globally, antimicrobial susceptibility of $E$. coli is studied in different foods depending on geographic region. In the European Union and the United States, emphasis is on meats and antibiotics such as cephalosporins and fluoroquinolones.[29,30] In Asia and Latin America, there are more studies on ready-to-eat foods.[31,32] This could be due to greater availability of inampicillin and sulfamethoxazole/trimethoprim (Table 3). A low percentage $(2.8 \%)$ of ES $\beta$ L enzyme was detected in $97 \mathrm{E}$. coli isolates obtained from fresh meats.

Geographical distribution of isolates (Table 4) showed that the highest percentage, $52.7 \%$ of the total, was identified in Havana Province at INHEM's laboratory. The percentage of isolates sent from provinces outside Havana was low. The highest percentage came from Santiago de Cuba (11.0\%); the rest were less than $10.0 \%$.

\section{DISCUSSION}

More than half of the bacterial isolates recovered from foods were resistant to at least one of the drugs tested. The most clinically important isolates were E. coli and Salmonella, since they often cause gastrointestinal disease or extraintestinal infections requiring treatment. The least effective antibiotics administered in vitro were tetracycline, ampicillin, nalidixic acid and penicillin, as also found in international studies.[16-20]

For WHO-classified antibiotics,[18] specifically those appropriate for only limited use in humans (including ciprofloxacin, cefotaxime, ceftriaxone and ceftazidime), resistance was low and observed more often in E. coli and Staphylococcus. The international literature reports resistance percentages higher than those in this study.[19-21] The foods that most often contained resistant isolates were meats and meat products; for Salmonella, this result is consistent with those of other researchers, which show that these products are among the main sources of resistant bacteria in this genus.[22,23]

The 173 Salmonella isolates from meats and meat products were obtained from 31 different foods. Hamburger showed the highest number of resistant isolates. Among fresh meats, resistance was most often found in poultry, where isolates from ground turkey were predominant, followed by those from ground chicken and mechanically deboned meat. These results agree with international reports, which found that in ground meats, the Salmonella detected often presents with high virulence and high levels of AMR.[24,25] dustrially processed ready-to-eat foods in developed countries while in developing nations there are more prepared foods sold by small-scale manufacturers who generally do not monitor product preparation, potentially allowing bacterial contaminants to survive and multiply. In this study, which analyzed meats and ready-to-eat foods, antibiotic resistance was frequent regardless of food type.

Currently, AMR in commensal bacteria such as $E$. coli is cause for growing concern because resistant genes can be replaced with bacteria that are pathogenic to humans. The scientific literature has demonstrated transfer of multidrug resistance through $E$. coli plasmids to other enterobacteria such as Salmonella.[33]

Most antibiotic-resistant Staphylococcus isolates were identified and hamburger. In milk and dairy products, most isolates were found in cheese, mainly artisanal cheeses. This last food group was shown to be associated with resistant isolates. Other countries report varying percentages of AMR to at least one of the antibiotics tested, among which $S$. aureus was the most prevalent in meats and cheeses.[21,34]

It should be noted that foodborne staphylococcal intoxication does not require antibiotic treatment, and there is no evidence that consuming foods contaminated with this bacteria is associated with infection in humans.[35] However, there is now special interest in antimicrobial susceptibility studies because of the possible transfer of resistant genes between microorganisms, and thus from the environment to humans.[7]

$V$. cholerae is a species endemic to aquatic environments, and thus may be an indicator of antibiotic resistance in bacteria found in these ecosystems. In this study, it was mainly found in fish, seafood and other fish products. Its expressed resistance was low except to ampicillin, to which resistance was seen in $>50 \%$ of isolates. No resistance was found to ciprofloxacin, azithromycin in meats and meat products such as sausages, ground meats 
or doxycycline, which are often used as first-line treatments for infections of toxigenic agents of this species. For V. cholerae, the international literature reports AMR usually higher than that found in this study.[36,37]

The highest percentage of isolates analyzed came from foods inspected at INHEM as part of the institution's responsibilities in sanitary registration including imported products and those domestically produced by various Cuban companies. Foods that do not meet the bacterial limits in the standard[11] are not approved for sale. However, there are currently no trade regulations that address antibacterial resistance, which is why studies focusing on risk are needed to accurately determine the scope of the problem.[38]

We observed an unequal distribution in both the number and geographic origin of isolates received from laboratories in other provinces participating in the study, as well as in numbers of isolates of each bacteria type received. There were low percentages of $E$. coli, Staphylococcus and V. cholerae, which made it impossible to analyze antibiotic resistance for each region of the country. This would be possible if a national antimicrobial resistance surveillance system were established to obtain standardized information that would allow comparisons by region and over time.
One of the study's main limitations was the unequal numbers of bacterial isolates sent from each province. The study was based on the isolates received, which did not allow nationally based analysis of a resistant bacterial load for each food. In addition, the information presented was obtained more than a year ago, which makes it invalid for immediate surveillance purposes, but does not affect its usefulness as a resource for illustrating a problem that demands surveillance and control. Despite these limitations, a broad range of antibiotics were analyzed, including most classes used in human and veterinary treatment, and the number of isolates studied for each bacterial genus was sufficient for making preliminary estimates of AMR prevalence in each case, although without claims as to their representativity.

\section{CONCLUSIONS}

Resistant phenotypes were identified in more than half the bacteria isolated from foods, with a higher percentage found in animal products such as meat, dairy, eggs and foods made from these ingredients. Low percentages of AMR were found for antibiotics classified as critical for human use. These results may serve as an alert to the dangers of acquiring foodborne antibiotic-resistant bacteria and demonstrate the need to establish a surveillance system and institute related control in Cuba.

\section{REFERENCES}

1. Comisión del Codex Alimentarius. Programa conjunto FAO/OMS Informe de situación sobre la resistencia a los antimicrobianos. 39o período de sesiones, Roma, 6 al13 de junio de 2015. C 2015/28 [Internet]. Rome: Food and Agricultural Organization; World Health Organization; 2015 Feb [cited 2016 Jul 18]. Available at: http://www.fao.org/fao-who-codex alimentarius/sh-proxy/en/?lnk=1\&url=https $\% 25$ $3 \mathrm{~A} \% 252 \mathrm{~F} \% 252 \mathrm{Fworkspace}$.fao.org $\% 252 \mathrm{Fsite}$ s\%252Fcodex $\% 252$ FMeetings $\% 252 F C X-701$ -39\%252FREPORT\%252FREP16_CACs.pdf. Spanish.

2. VII Taller Nacional del Comisión del Codex Alimentarius. Por una acción integrada frente a la resistencia antimicrobiana, 17 de marzo de 2017 [Internet]. Havana: Pan American Health Organization; 2017 [cited 2018 Jul 18]. Available at: http://www.paho.org/cub/index.php?option=com _docman\&view=download\&alias=1516-vii-taller -nacional-del-codex-alimentarius\&category_slug =articulos-completos-para-web\&Itemid=226. Spanish.

3. Quiñones Pérez D. Resistencia antimicrobiana: evolución y perspectivas actuales ante el enfoque "Una salud". Rev Cubana Med Trop [Internet]. 2017 [cited 2018 Jul 17];69 (3). Available at: Available at: http://www.revmedtropical.sld .cu/index.php/medtropical/article/view/263/182. Spanish.

4. Capita R, Alonso-Calleja C. Antibiotic-resistant bacteria: a challenge for the food industry. Crit Rev Food Sci Nutr. 2012 Oct 4 3;53(1):11-48.

5. European Food Safety Authority; European Center for Disease Prevention and Control. The European Union summary report on antimicrobial resistance in zoonotic and indicator bacteria from humans, animals and food in 2017. EFSA Journal [Internet]. 2019 [cited 2019 Mar 22];17(2):5598. Available at: https://ecdc.europa .eu/sites/portal/files/documents/EU-summary-re port-antimicrobial-resistance-zoonotic-bacteria -humans-animals-2017-web.pdf

6. De Roda Husman AM, Joakim Larsson DG. Risk assessment and risk management of antimi- crobial resistance in the environment [Internet] Suffolk: AMR Control; 2016 Jul 14 [cited 2020 May 25]. Available at: http://resistancecontrol .info/2016/amr-in-food-water-and-the-environ ment/risk-assessment-and-risk-management-of -antimicrobial-resistance-in-the-environment/

7. World Health Organization. Integrated surveillance of antimicrobial resistance in foodborne bacteria: application of a one health approach: guidance from the WHO Advisory Group on Integrated Surveillance of Antimicrobial Resistance (AGISAR) [Internet]. Geneva: World Health Organization; 2017 [cited 2018 Jun 11]. Available at: https://apps.who.int/iris/handle/10665/255747

8. UNE Normalización Española [Internet]. Madrid: UNE Normalización Española; c2020. Normalización. Proyectos. Microbiología de Alimentación Humana y Animal. Método horizontal para la enumeración de Escherichia Coli $\beta$-Glucoronidasa positiva. Parte 2: (ISO 166492); 2013 [cited 2020 May 25]. Available at: https:// www.une.org/encuentra-tu-norma/busca-tu-nor $\mathrm{ma}$ /proyecto?c=P0036634. Spanish.

9. UNE Normalización Española [Internet]. Madrid: UNE Normalización Española; c2020. Norma. Microbiología de los alimentos para consumo humano y alimentación animal. Método horizontal para la detección de Salmonella spp. (UNE. EN ISO 6579:2003); 2017 [cited 2020 May 25]. Available at: https://www.une.org/encuentra-tu -norma/busca-tu-norma/norma/?c=N0028651. Spanish.

10. UNE Normalización Española [Internet]. Madrid: UNE Normalización Española; c2020. Microbiología de los alimentos para consumo humano y alimentación animal. Método horizontal para la enumeración de Staphylococcus coagulasa positiva (Staphylococcuus aureus y otras especies). Parte 1: Técnica Utilizando el Medio agar baird parker (ISO 6888-1); 2003 [cited 2020 May 25]. Available at: https://www.une.org/encuentra -tu-norma/busca-tu-norma/norma?c=N0030548. Spanish.

11. International Organization for Standardization (ISO). Geneva: International Organization for
Standardization; c2020. Store. Microbiology of the food chain -- Horizontal method for the determination of Vibrio spp. Part 1: Detection of potentially enteropathogenic Vibrio parahaemolyticus, Vibrio cholerae and Vibrio vulnificus (ISO 218721:2017); 2017 Jun [cited 2020 May 25]. Available at: https://www.iso.org/standard/74112.html

12. Contaminantes Microbiológicos en Alimentos NC 585-Requisitos Sanitarios. Havana: Oficina Nacional de Normalización (CU); 2017. Spanish.

13. Clinical and Laboratory Standards Institute (CLSI). M100-S25. Performance Standards for Antimicrobial Susceptibility Testing; Twenty-Fifth Informational Supplement. Vol 35 No 3. Philadelphia: Clinical and Laboratory Standards Institute (CLSI); 2015 Jan. 243 p.

14. World Health Organization. WHONET 5.6. Software para la vigilancia de la resistencia antimicrobiana y control de infecciones [Internet]. Geneva: World Health Organization; 2008 [cited 2010 Jul 8]. Available at: http://www.who.int/drug resistance/whonetsoftware/. Spanish.

15. Pan American Health Organization; Xunta de Galicia Dirección Xeral de Saúde Pública. EPIDAT [Internet]. Washington, D.C.: Pan American Health Organization; [cited 2020 May 25]; [about 4 screens]. Available at: https://www.paho.org/ spanish/sha/epidat.htm. Spanish.

16. Andersen JL, He GX, Kakarla P, Ranjana KC, Kumar S, Lakra WS, et al. Multidrug efflux pumps from Enterobacteriaceae, Vibrio cholerae and Staphylococcus aureus bacterial food pathogens. Int J Environ Res Public Health. 2015 Jan 27;12(2):1487-547.

17. Zhu Y, Lai H, Zou L, Yin S, Wang C, Han X, et al. Antimicrobial resistance and resistance genes in Salmonella strains isolated from broiler chickens along the slaughtering process in China. Int Jour Food Microb [Internet]. 2017 Oct 16 [cited 2018 Feb 20];259:43-51. Available at: https://doi .org/10.1016/j.ijfoodmicro.2017.07.023

18. World Health Organization. Global priority list to guide research, discovery, and development of new antibiotics [Internet]. Geneva: World Health Organization; 2017 [cited 2017 Mar 15]. 
7 p. Available at: http://www.who.int/medicines/ publications/WHO-PPL-Short_Summary_25Feb -ET_NM WHO.pdf

19. Hille K, Ruddat I, Schmid A, Hering J, Hartmann $M$, von Münchhausen $C$, et al. Cefotaximeresistant $E$. coli in dairy and beef cattle farms-joint analyses of two cross-sectional investigations in Germany. Prev Vet Med. 2017 May 2:142:39-45.

20. Ojer-Usoz E, González D, Vitas AI. Clonal diversity of ESBL-producing Escherichia coli isolated from environmental, human and food samples. Int J Environ Res Public Health [Internet]. 2017 [cited 2018 Mar 9];14(7):676. Available at: https:// www.ncbi.nlm.nih.gov/pubmed/28644413

21. Igbinosa EO, Beshiru A, Akporehe LU, Oviasogie FE, Igbinosa OO. Prevalence of methicillin-resistant Staphylococcus aureus and other Staphylococcus species in raw meat samples intended for human consumption in Benin City, Nigeria: implications for Public Health. Int J Environ Res Public Health [Internet]. 2016 Sep 24 [cited 2016 Jul 16];13(10):949. Available at: http://dx.doi .org/10.3390/ijerph13100949

22. Bai L, Zhao J, Gan X, Wang J, Zhang X, Cui S, et al. Emergence and diversity of Salmonella enterica serovar Indiana isolates with concurrent resistance to ciprofloxacin and cefotaxime from patients and food-producing animals in China. Antimicrob Agents Chemother. 2016 May 22;60(6):3365-71.

23. Shilangale RP, Kaaya G, Chimwamurombe P. Antimicrobial resistance patterns of Salmonella strains isolated from beef in Namibia. BMRJ. 2016;12(1):1-6.

24. Ballesteros N, Rubio-Lozano MS, DelgadoSuárez E, Méndez-Medina D, Braña-Varela $D$, Rodas-Suárez O. Perfil de resistencia a antibióticos de serotipos de Salmonella spp. aislados de carne de res molida en la Ciudad de México. Salud Pública Méx (Cuernavaca) [Internet] 2016 May-Jun [cited 2017 Oct 23];58(3):37177. Available at: http://www.scielo.org.mx/ scielo.php?script=sci arttext\&pid=S0036-36 $342016000300371 \&$ Ing=es. Spanish.

25. Shah DH, Paul NC, Sischo WC, Crespo R, Guard $J$. Population dynamics and antimicrobial resistance of the most prevalent poultry-associated Salmonella serotypes. Poultry Sci. 2017 Mar 1:96(3):687-702.

26. Ramírez A. La avicultura cubana: un futuro prometedor. El Sitio Avícola [Internet]. 2014 Jun [cited 2016 Feb 2];Artículos:[about 3 p.]. Interview by Chris Wright. Available at: http://www.elsitioavi cola.com/articles/2561/la-avicultura-cubana -un-futuro-prometedor/\#sthash.wP6EzD6d.pdf. Spanish.

27. Eibach D, Dekker D, Gyau Boagen K, Akenten CW, Sarpong N, et al. Extended-spectrum betalactamase-producing Escherichia coli and Klebsiella pneumoniae in local and imported poultry meat in Ghana. Vet Microbiol [Internet]. 2018 Apr [cited 2019 Jul 16];217:7-12. Available at: https:// doi.org/10.1016/j.vetmic.2018.02.023

28. Ruiz-Roldán L, Martínez-Puchol S, Gomes C, Palma N, Riveros M, Ocampo K, et al. Presencia de Enterobacteriaceae y Escherichia coli multirresistente a antimicrobianos en carne adquirida en los mercados tradicionales en Lima, Perú Rev Perú Med Exp Salud Pública. 2008 JulSep;35(3):425-32. Spanish

29. Markland S, Weppelmann TA, Ma Z, Lee S, Mir RA, Teng L, et al. High prevalence of cefotaxime resistant bacteria in grazing beef cattle: a cross sectional study. Front Microbiol. $2019 \mathrm{Feb}$ 6;10:176. DOI: 10.3389/fmicb.2019.00176

30. Caruso G, Giammanco A, Cardamone C, Oliver G, Mascarella C, Capra G, et al. Extra-intestina fluoroquinolone-resistant Escherichia coli strains isolated from meat. Biomed Res Int [Internet] 2018 Nov 18 [cited 2019 Jul 16];2018(Special Issue):8714795. Available at: https://www.hindawi .com/journals/bmri/2018/8714975/

31. Baloch $A B$, Yang $H$, Feng $Y, X i M$, Wu $Q$, Yang $Q$, et al. Presence and antimicrobial resistance of Escherichia coli in ready-to-eat foods in Shaanxi, China. J Food Prot. 2017 Feb 28;80(3):420-4.

32. Arenas NE, Abril DA, Valencia P, Khandige $S$ Soto CY, Moreno-Melo V. Screening food-borne and zoonotic pathogens associated with livestock practices in the Sumapaz region, Cundinamarca, Colombia. Trop Anim Health Prod. 2017 Mar 10;49(4):739-45.

33. Card RM, Cawthraw SA, Nunez-García J, Ellis RJ, Kay G, Pallen MJ, et al. An In vitro chicken gut model demonstrates transfer of a multidrug resistance plasmid from Salmonella to commensal Escherichia coli. mBio [Internet]. 2017 Jul 17 [cited 2018 Feb 2];8(4). Available at: http://mbio .asm.org/content/8/4/e00777-17.full

34. Wang W, Baloch Z, Jiang T, Zhang C, Peng Z Li F. Enterotoxigenicity and antimicrobial resistance of Staphylococcus aureus isolated from retail food in China. Front Microbiol. 2017 Nov 20;8:2256. DOI: 10.3389/fmicb.2017.02256

35. Osman K, Álvarez-Ordóñez A, Ruiz L, Badr J, El Hofy F, Al-Maary KS, et al. Antimicrobial resistance and virulence characterization of Staphylococcus aureus and coagulase-negative Staphylococci from imported beef meat. Ann Clin Microbiol Antimicrob [Internet]. 2017 May 10 [cited $2018 \mathrm{Jul}$ 8];16:35. Available at: http://dx.doi .org/10.1186/s12941-017-0210-4

36. Bier N, Schwartz K, Guerra B, Strauch E. Survey on antimicrobial resistance patterns in Vibrio vulnificus and Vibrio cholerae non-O1/non-0139 in Germany reveals carbapenemase-producing Vibrio cholerae in coastal waters. Front Microbiol [Internet]. 2015 Oct 27 [cited 2018 Feb 20] 6:1179. Available at: http://journal.frontiersin.org/ article/10.3389/fmicb.2015.01179

37. Feglo PK, Sewurah M. Characterization of highly virulent multidrug resistant Vibrio cholerae isolated from a large cholera outbreak in Ghana. BMC [Internet]. 2018 Jan 17 [cited 2019 Jul 16];11(1):45. Available at: https://europepmc.org/ article/pmc/pmc5774149

38. Comisión del Codex Alimentarius. Directrices para el análisis de riesgos de resistencia a los antimicrobianos transmitida por los alimentos CAC/GL 77-2011 [Internet]. Rome: Food and Ag- riculture Organization; 2011 [cited 2019 Sep 18] 34 p. Available at: www.fao.org/input/download/ standards/11776/CXG 077s.pdf. Spanish.

\section{THE AUTHORS}

Yamila Puig-Peña (Corresponding author: yamilapuig@infomed.sld.cu), physician specializing in microbiology with a master's degree in nutrition in public health and infectious diseases. Associate researcher and professor, Microbiology Laboratory, National Institute of Hygiene, Epidemiology and Microbiology (INHEM), Havana, Cuba. https://orcid.org/0000-0003-2404-123X

Virginia Leyva-Castillo, biochemist specializing in microbiology and a master's degree in infectious diseases. Researcher and associate professor, laboratory department, sanitary microbiology section, INHEM, Havana, Cuba. https://orcid.org/0000-0002-3332-6475

René Tejedor-Arias, food and nutrition scientist with a doctorate in nutrition. Full professor, Food and Pharmacy Institute, University of Havana, Cuba. https://orcid.org/0000-0002-8131-0590

María Teresa IlInait-Zaragozí, physician specializing in microbiology with a doctorate in medical sciences. Researcher and full professor, Bacteriology and Mycology Department, Pedro Kourí Tropical Medicine Institute (IPK), Havana, Cuba. https://orcid.org/0000-0002-8929-6172

Neibys Aportela-López, food and nutrition scientist. Adjunct researcher, laboratory department, sanitary microbiology section, INHEM, Havana, Cuba. https://orcid.org/0000-0003-3785 $-6462$

Ailen Camejo-Jardines, medical technologist with a focus on microbiology, laboratory department, sanitary microbiology section, INHEM, Havana, Cuba. https://orcid.org/0000-0001-9498 $-3308$

Jesy Ramírez-Areces, food and nutrition scientist, Food and Pharmacy Institute, University of Havana, Cuba.

Submitted: November 7, 2019

Approved for publication: July 6, 2020

Disclosures: None 